\title{
Lupoid mucocutaneous leishmaniasis
}

\section{Leiszmanioza śluzówkowo-skórna: postać toczniowa}

Tizita Yosef', Radomir P. Reszke², Jacek Szepietowski²

'Department of Dermatovenereology, Addis Ababa University, Ethiopia

2Department of Dermatology, Venereology and Allergology, Wroclaw Medical University, Wroclaw, Poland

'Klinika Dermatowenerologii Uniwersytetu w Addis Abebie, Etiopia

${ }^{2}$ Katedra i Klinika Dermatologii, Wenerologii i Alergologii Uniwersytetu Medycznego we Wrocławiu, Polska

Dermatol Rev/Przegl Dermatol 2018, 105, 534-541

DOI: https://doi.org//0.51/4/dr.2018.78074

\section{CORRESPONDING AUTHOR/} ADRES DO KORESPONDENCJI: prof. dr hab. n. med. Jacek Szepietowski Katedra i Klinika Dermatologii, Wenerologii i Alergologii Uniwersytet Medyczny we Wrocławiu ul. T. Chałubińskiego 1 50-368 Wrocław, Polska tel.: +48 601534853 e-mail: jacek.szepietowski@ umed.wroc.pl

\begin{abstract}
Introduction. Leishmaniasis is a parasitic infection caused by different species of the intracellular protozoan Leishmania and transmitted through the bite of an infected female sand fly. It occurs in various clinical forms, including cutaneous manifestations.

Objective. To present a case of lupoid mucocutaneous leishmaniasis in a patient from Ethiopia.

Case report. A 17-year-old man with no significant medical history presented with papular, plaque and ulcerative lesions in the central region of face that had been present for one year. A smear followed by Giemsa stain revealed the presence of amastigotes in monocytes and extracellular matrix. Based on the clinical manifestation and microscopic examination, the diagnosis of mucocutaneous leishmaniasis was established. The treatment was based on $\mathrm{N}$-methylglucamine antimoniate, with subsequent resolution of skin lesions.

Conclusions. Mucocutaneous leishmaniasis, including the lupoid subtype, is an important clinical entity in endemic areas. Treatment with antimony derivatives may be beneficial in affected subjects.
\end{abstract}

\section{STRESZCZENIE}

Wprowadzenie. Leiszmanioza jest chorobą pasożytniczą wywołaną przez różne gatunki wewnątrzkomórkowych pierwotniaków z rodzaju Leishmania, przenoszoną przez ukąszenie zakażonej samicy muchówki. Choroba może mieć różne obrazy kliniczne, w tym objawy skórne.

Cel pracy. Opis przypadku postaci toczniowej leiszmaniozy skórno-śluzówkowej u pacjenta z Etiopii.

Opis przypadku. Mężczyzna 17-letni bez istotnej przeszłości chorobowej zgłosił się ze zmianami grudkowymi, blaszkowymi oraz owrzodzeniami zlokalizowanymi w centralnej części twarzy, które pojawiły się około roku wcześniej. Wykonano wymaz metodą odciskową z następczym barwieniem metodą Giemsy, co uwidoczniło obecność amastygotów w monocytach i macierzy zewnątrzkomórkowej. Na podstawie obrazu klinicznego oraz badania mikroskopowego ustalono rozpoznanie postaci toczniowej leiszmaniozy śluzówkowo-skórnej. W leczeniu zastosowano antymonian N-metyloglukaminy i uzyskano ustąpienie zmian skórnych. 
Wnioski. Leiszmanioza śluzówkowo-skórna, także w odmianie toczniowej, stanowi ważną jednostkę chorobową w rejonach endemicznych. Terapia pochodnymi antymonu może przynosić korzyści pacjentom $\mathrm{z}$ tym schorzeniem.

Key words: mucocutaneous leishmaniasis, lupoid subtype, diagnosis. Słowa kluczowe: leiszmanioza śluzówkowo-skórna, postać toczniowa, diagnoza.

\section{INTRODUCTION}

Leishmaniasis is a parasitic infection caused by different species of the intracellular protozoan Leishmania and transmitted through the bite of an infected female sand fly $[1,2]$. It is an important disease with a wide spectrum of clinical manifestations, posing a public health problem in many parts of the world. Around 23 species of Leishmania are responsible for one of the three clinical forms of the disease: cutaneous, mucosal and visceral leishmaniasis [2, 3].

It is endemic in more than 98 countries, approximately $90 \%$ of the cases being reported in Africa, including Ethiopia. Globally, it is estimated that 350 million people are at risk of contracting the disease. The overall prevalence is 12 million cases and the annual incidence is $2-2.5$ million cases, including 0.5 million cases of visceral leishmaniasis and 1.5 million of cutaneous leishmaniasis (CL) $[3,4]$.

Based on the geographic region where the infection is acquired, the disease is divided into two subsets: old world and new world. Old world leishmaniasis is caused by Leishmania species found in Africa, Asia, the Middle East, the Mediterranean region, and India. New world leishmaniasis is caused by Leishmania species found in Central and South America. The causative organisms, vectors, reservoirs, clinical manifestations, and prognosis are different in these groups. The usual causes of old world cutaneous leishmaniasis are L. major, L. tropica or L. aethiopica [4].

Cutaneous leishmaniasis occurs in a variety of clinical forms: local cutaneous leishmaniasis (LCL), diffuse cutaneous leishmaniasis (DCL), and mucocutaneous leishmaniasis (MCL), depending on the responsible subspecies of the Leishmania involved, and host related factors. The clinical lesions may vary in terms of type and extension, ranging from single, chronic ulcerative lesions to disseminated nodular lesions. However, several unusual and atypical clinical features of the disease have been reported recently $[5,6]$.

\section{WPROWADZENIE}

Leiszmanioza jest chorobą pasożytniczą wywoływaną przez różne gatunki wewnątrzkomórkowych pierwotniaków z rodzaju Leishmania, przenoszoną przez ukąszenie zakażonej samicy muchówki [1, 2]. Jest to schorzenie o dużym znaczeniu, które charakteryzuje się szerokim zakresem obrazów klinicznych i stanowi istotny problem zdrowia publicznego w wielu regionach świata. Leiszmanioza może przebiegać w trzech postaciach klinicznych: skórnej, śluzówkowej i trzewnej. Za ich rozwój odpowiadają 23 gatunki pasożytów z rodzaju Leishmania $[2,3]$.

Choroba ma charakter endemiczny w ponad 98 krajach. Około 90\% przypadków odnotowuje się w Afryce, w tym w Etiopii. Szacuje się, że globalnie ryzyko zachorowania dotyczy 350 milionów osób. Ogólną chorobowość szacuje się na 12 milionów, a roczna zapadalność wynosi 2-2,5 miliona przypadków, w tym 0,5 miliona przypadków leiszmaniozy trzewnej i 1,5 miliona przypadków leiszmaniozy skórnej (cutaneous leishmaniasis - CL) $[3,4]$.

W zależności od regionu geograficznego, w którym dochodzi do zakażenia, chorobę dzieli się na dwa podtypy: leiszmaniozę starego świata i nowego świata. Leiszmaniozę starego świata wywołują gatunki z rodzaju Leishmania występujące w Afryce, Azji, krajach Bliskiego Wschodu, rejonie Morza Śródziemnego i Indiach. Leiszmaniozę nowego świata powodują gatunki Leishmania z Ameryki Środkowej i Południowej. Pomiędzy podtypami istnieją różnice dotyczące organizmów wywołujących chorobę, wektorów, rezerwuarów, objawów klinicznych i rokowania. Leiszmaniozę skórną starego świata powodują zazwyczaj gatunki L. major, L. tropica lub L. aethiopica [4].

Leiszmanioza skórna występuje w różnych postaciach klinicznych: miejscowej leiszmaniozy skórnej (local cutaneous leishmaniasis - LCL), rozlanej leiszmaniozy skórnej (diffuse cutaneous leishmaniasis - DCL) i leiszmaniozy śluzówkowo-skórnej (mucocutaneous leishmaniasis - MCL), w zależności od wywołującego chorobę podgatunku Leishmania oraz czynników zwią- 


\section{OBJECTIVE}

In this case report, we describe a rare variant of lupoid mucocutaneous leishmaniasis located on the face, resembling other granulomatous cutaneous conditions of infectious or inflammatory origin, with successful treatment with systemic meglumine antimoniate.

\section{CASE REPORT}

A 17-year-old male Ethiopian patient presented with one year history of skin lesions in the central region of the face. The initial lesion started as a small painless papule over the nose, which slowly progressed to form an infiltrative plaque. Two months after the initial papule, the lesions gradually enlarged and spread peripherally to cover a large part of his cheeks with associated ulceration and edema. The patient had no significant past medical history, but he was from a leishmaniasis endemic area and there was a similar issue in the vicinity.

Cutaneous examination revealed extensive confluent slightly erythematous indurated papules and plaques in the center of the face, with a crusted ulcer on the nasal bridge and right ala and involvement of the nasal mucosa (fig. $1 \mathrm{~A}-\mathrm{C}$ ). No fever or palpable regional lymph nodes were found. Systemic physical examination was normal.

Clinical features were consistent with lupoid MCL. Routine laboratory tests were within normal limits and the HIV serology test was negative. A direct microscopic examination of tissue impression smears stained with Giemsa was performed and demon- zanych z gospodarzem. Zmiany kliniczne mogą mieć różny rodzaj i rozległość - od pojedynczych, przewlekłych zmian wrzodziejących aż po rozsiane zmiany guzkowe. Ostatnio pojawiły się jednak doniesienia o nietypowych objawach klinicznych w przebiegu choroby $[5,6]$.

\section{CEL PRACY}

W pracy przedstawiono przypadek rzadkiej toczniowej postaci leiszmaniozy śluzówkowo-skórnej umiejscowionej w obrębie twarzy, przypominającej inne ziarniniakowe choroby skóry o podłożu zakaźnym lub zapalnym, skutecznie leczonej ogólnoustrojowo antymonianem megluminy.

\section{OPIS PRZYPADKU}

Etiopczyk 17-letni zgłosił się z utrzymującymi się od roku zmianami skórnymi zlokalizowanymi w centralnej części twarzy. Pierwotnie zmiana skórna miała postać niewielkiej, niebolesnej grudki na nosie, która uległa powolnej progresji i utworzyła nacieczoną blaszkę. Przez dwa miesiące od pojawienia się początkowej zmiany, zmiany skórne stopniowo powiększały się i rozprzestrzeniały obwodowo, zajmując znaczną część skóry na policzkach z pojawieniem się owrzodzenia i obrzęku. W wywiadzie chorobowym nie stwierdzono istotnych obciążeń, jednak pacjent pochodził z obszaru, na którym leiszmanioza jest chorobą endemiczną, a w okolicy stwierdzono podobny przypadek.

Badanie przedmiotowe wykazało umiejscowione w centralnej części twarzy rozległe, zlewne zmiany o nieznacznym podłożu rumieniowym w postaci
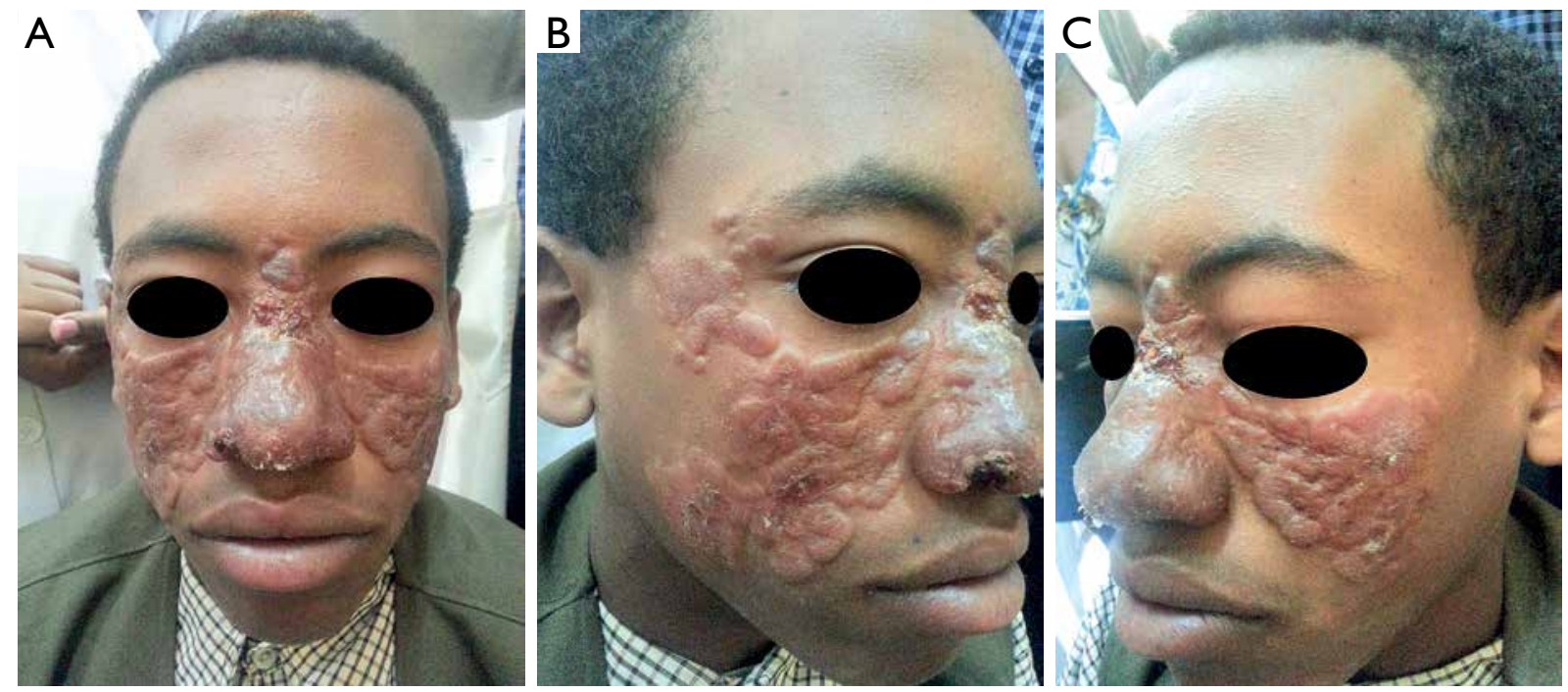

Figure I A-C. Confluent, slightly erythematous indurated papules and plaques in the center of the face. A crusted ulcer on the nasal bridge and right ala involving the nasal mucosa is also apparent

Rycina I A-C. Zlewne zmiany o nieznacznym podłożu rumieniowym w postaci stwardniałych grudek i blaszek w centralnej części twarzy. Na grzbiecie nosa i prawym skrzydełku owrzodzenie pokryte strupem, z zajęciem śluzówek 


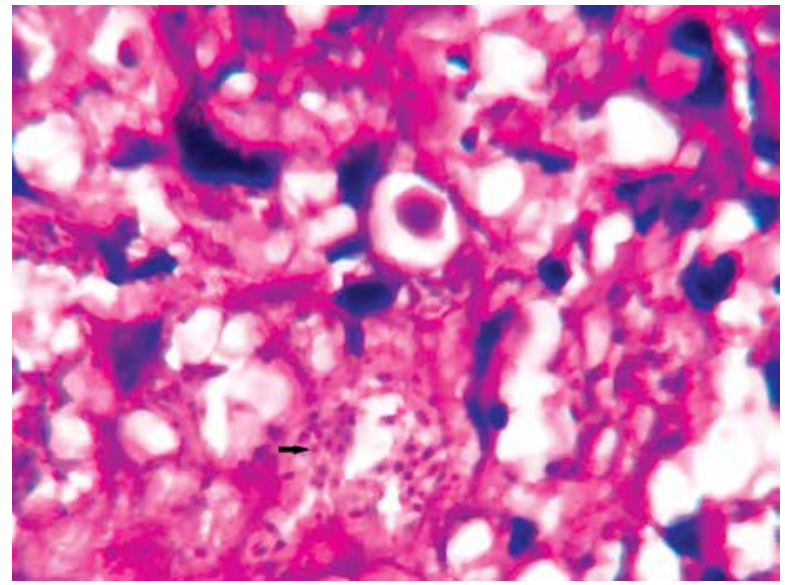

Figure 2. Numerous amastigotes of Leishmania species in both monocytes and extracellular matrix (Giemsa stain, I00× magnification) Rycina 2. Liczne amastygoty z rodzaju Leishmania w obrębie monocytów i macierzy zewnątrzkomórkowej (barwienie metodą Giemsy, powiększenie $100 \times$ )

strated numerous amastigotes of Leishmania species in both monocytes and extracellularly (fig. 2). Therefore, the diagnosis of lupoid MCL was confirmed in direct microscopic examination.

The patient was put on intramuscular injections of N-methylglucamine antimoniate $30 \mathrm{mg} / \mathrm{kg} /$ day for 45 consecutive days with local wound care. After completion of the first cycle of systemic meglumine antimoniate for 45 days, the clinical response was satisfactory and the lesions became less indurated, smoother and the ulcerated lesions healed (fig. 3, 4). However, repeated direct microscopy examinations demonstrated amastigotes. Therefore, we decided to continue a second cycle of treatment

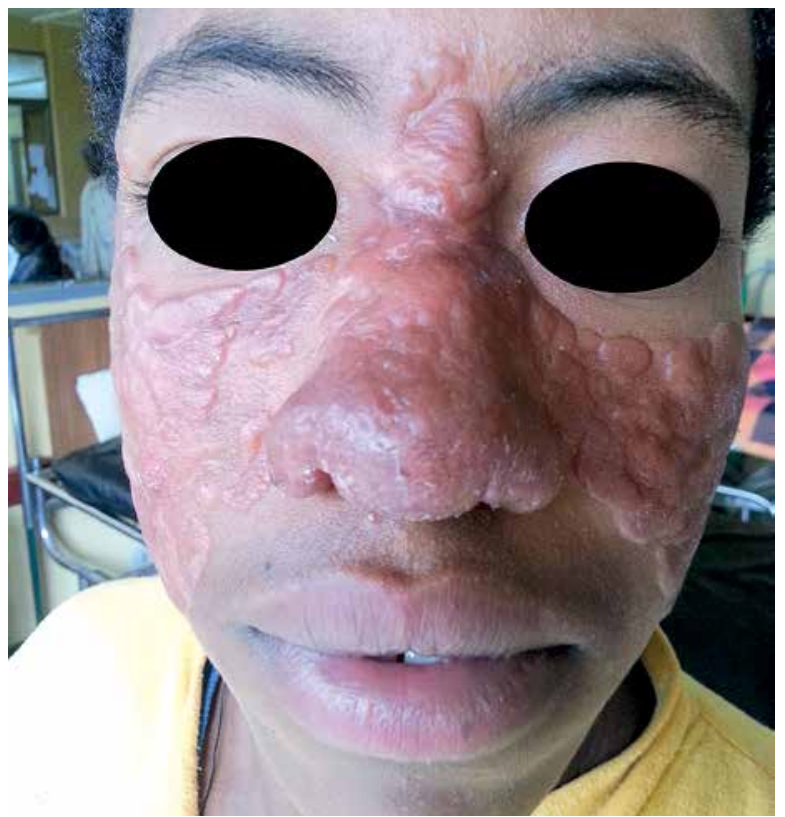

Figure 3. Skin lesions during $\mathrm{N}$-methylglucamine antimoniate treatment (20 th day)

Rycina 3. Zmiany skórne w trakcie terapii antymonianem N-metyloglukaminy (20. dzień terapii) stwardniałych grudek i blaszek, jak również pokryte strupem owrzodzenie na grzbiecie i prawym skrzydełku nosa z zajęciem śluzówek (ryc. 1 A-C). Nie stwierdzono gorączki ani wyczuwalnych palpacyjnie regionalnych węzłów chłonnych. Badanie przedmiotowe w zakresie poszczególnych układów nie wykazało żadnych nieprawidłowości.

Obraz kliniczny wskazywał na postać toczniową MCL. Wyniki podstawowych badań laboratoryjnych mieściły się w granicach normy. Badanie serologiczne wykrywające wirus HIV dało wynik ujemny. Wykonano bezpośrednie badanie mikroskopowe wymazów materiału tkankowego pobranego metodą odciskową z barwieniem metodą Giemsy. Stwierdzono

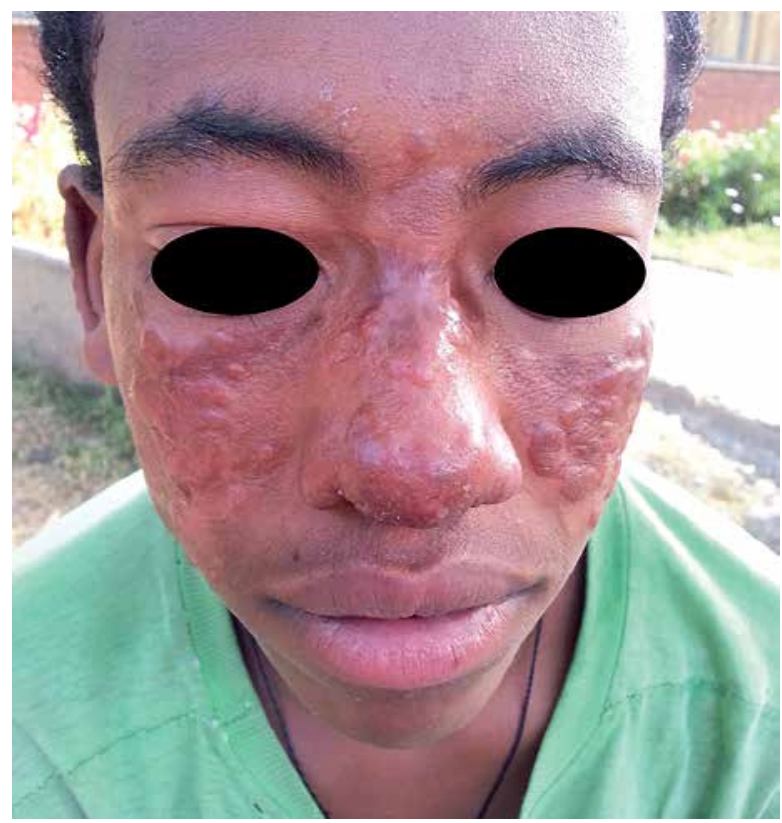

Figure 4. Skin lesions after completion of the first cycle of treatment

Rycina 4. Zmiany skórne po zakończeniu pierwszego cyklu leczenia 
after conducting a revised baseline investigation. After a 2-week break the patient started the same treatment with the same dose and duration. Following completion of the second cycle, flattening of the infiltrated plaque and satellite papules was achieved. The patient was followed for 6 months after 2 cycles of treatment and no relapse was observed.

\section{DISCUSSION}

Cutaneous leishmaniasis is endemic in Ethiopia and widely distributed all over the country. It predominantly affects children, adolescents and young adults. The annual CL burden is estimated at around 20000 to 40000 cases per year. A recent study estimated almost 30 million of Ethiopians to be at risk for CL. Because of its morbidity and disfiguring scars, it is still considered a serious public health problem. In Ethiopia, CL is almost always caused by L. aethiopica (99\%). Cutaneous leishmaniasis caused by L. aethiopica gives rise to slower-growing ulcers than the other old world types. This type also takes longer to heal, usually between 2 and 5 years, and requires systemic treatment [7-11]. Additionally, the possibility of infection has to be taken into account in European countries as well, especially in individuals returning from vacations in endemic areas, as demonstrated by Polish [12] or German investigators [13].

Cutaneous leishmaniasis has many clinical manifestations. Apart from the classical ulcero-crusted form, unusual clinical variants were reported, including lupoid, erysipeloid, verrucous, sporotrichoid, psoriasiform, zosteriform, linear, mycetomatous, squamous cell carcinoma-like and eczematous forms, which creates difficulties in establishing the clinical diagnosis [5, 14, 15]. For this reason, all cases of atypical CL should be confirmed by demonstration of the parasite.

The reasons for unusual manifestations are unclear, but several lines of clinical and experimental evidence indicate that alteration in the host's immune response, co-morbidities, malnutrition and genetic diversity among strains can influence the evolution and outcome of the broad clinical form of CL [14-16]. However, some unusual forms do not seem to be related to obvious risk factors, as in our immunocompetent patient. Thus, further studies are needed to explain the diversity of disease forms.

The main factors responsible for the delays or difficulties in arriving at the diagnosis of CL were usually clinical presentations mimicking other diseases $[17,18]$. A high index of suspicion and including CL in the differential diagnosis of granulomatous cutaneous conditions are very important for early diagnosis obecność licznych amastygotów gatunku Leishmania zarówno w monocytach, jak i w macierzy zewnątrzkomórkowej (ryc. 2). W ten sposób, na podstawie wyników bezpośredniego badania mikroskopowego, potwierdzono rozpoznanie postaci toczniowej MCL.

Wdrożono leczenie antymonianem N-metyloglukaminy podawanym $w$ iniekcjach domięśniowych w dawce $30 \mathrm{mg} / \mathrm{kg}$ m.c./dobę przez 45 kolejnych dni oraz miejscową pielęgnację rany. Po zakończeniu pierwszego cyklu ogólnoustrojowej terapii antymonianem megluminy (45 dni) odpowiedź kliniczną na leczenie uznano za zadowalającą. Zmniejszył się stopień stwardnienia skóry w obrębie zmian, skóra się wygładziła, a owrzodzenia wygoiły (ryc. 3, 4). W ponownych bezpośrednich badaniach mikroskopowych stwierdzono jednak amastygoty. Podjęto decyzję o włączeniu kolejnego cyklu leczenia po powtórzeniu badań laboratoryjnych. Po 2-tygodniowej przerwie pacjent rozpoczął drugi cykl leczenia o takim samym czasie trwania i z zastosowaniem tej samej dawki. Po zakończeniu drugiego cyklu nacieczona blaszka i satelitarne zmiany grudkowe uległy spłaszczeniu. Pacjent był pod obserwacją przez 6 miesięcy od zakończenia 2 cykli leczenia. W tym czasie nie stwierdzono nawrotu choroby.

\section{OMÓWIENIE}

Leiszmanioza skórna jest w Etiopii chorobą endemiczną i jest rozpowszechniona na całym terytorium kraju. Występuje głównie u dzieci, młodzieży i młodych osób dorosłych. Roczna zachorowalność na CL wynosi 20 000-40 000 przypadków. W niedawnym badaniu oszacowano, że ok. 30 milionów Etiopczyków jest narażonych na zachorowanie na CL. Ze względu na chorobowość i ryzyko powstania szpecących blizn CL uznaje się za istotny problem zdrowia publicznego. W Etiopii czynnikiem wywołującym CL jest niemal zawsze L. aethiopica (99\%). Leiszmanioza skórna wywoływana przez L. aethiopica powoduje owrzodzenia, które rozwijają się wolniej niż w przebiegu innych odmian leiszmaniozy starego świata. Dłużej trwa również jej leczenie - zazwyczaj od 2 do 5 lat, a pacjenci wymagają terapii ogólnoustrojowej [7-11]. Jak wykazali polscy [12] i niemieccy [13] badacze, możliwość zakażenia należy brać pod uwagę także w krajach europejskich, zwłaszcza u osób, które przebywały na urlopie na obszarach endemicznego występowania choroby.

Leiszmanioza skórna ma różnorodne obrazy kliniczne. Oprócz klasycznej postaci z owrzodzeniami i strupami opisywano także nietypowe warianty kliniczne, m.in. odmianę toczniową, różycową, brodawkowatą, sporotrychoidalną, łuszczycopodobną, półpaścopodobną, linijną, grzybniakową, przypominającą raka płaskonabłonkowego skóry oraz wypryskową. Duża liczba postaci prowadzi do trudności 
and prompt treatment of this disfiguring disease. In Ethiopia, most patients do not present any diagnostic difficulties and the diagnosis is often made clinically. But some patients show very unusual morphological forms which elude diagnosis in the first instance. In this situation, microscopic examination can be performed. The use of more sophisticated diagnostic techniques that allow for species identification is usually restricted only to research due to the cost.

Lupoid CL is a rare form of CL. It is most prevalent in the endemic areas of leishmaniasis, particularly in the Middle East and Afghanistan. In the literature, L. tropica is thought to be the most frequent causative agent of lupoid CL. This form of the disease has a striking resemblance to other granulomatous cutaneous conditions of infectious or inflammatory origin $[19,20]$. Lupoid CL on the face resembling that of lupus vulgaris, leprosy or lupus erythematosus is frequently seen in Ethiopia nowadays. Although we were not able to identify the species due to cost restrictions, it seems likely that in our patient L. aethiopica was the causative organism.

Treatment depends on the region of the world in which the infection was acquired, the species of Leishmania, the site and severity of the infection, and host factors, such as immune status and age [21, 22]. Lupoid CL is usually resistant to conventional therapies for CL and it may persist and spread slowly for many years [19]. In the absence of randomized controlled trials, there are not enough data about the proper therapeutic protocol for the treatment of lupoid CL. Many treatments have been reported in the last few years to be used as monotherapy, such as cryotherapy, paromomycin ointment, intralesional injections of sodium stibogluconate, oral itraconazole, oral fluconazole, pentamidine, and miltefosine, with varying degrees of success [23-25]. However, another study showed that carbon dioxide laser seemed to be highly effective since it led to $90 \%$ efficacy in treating 24 patients with lupoid CL [26]. Still, pentavalent antimonials are the first-line choice of treatment in Ethiopia [7, 10].

In our patient, considering the distractive and slowly disfiguring nature of lupoid MCL on the face, we initiated systemic meglumine antimoniate with a dose of $30 \mathrm{mg} / \mathrm{kg} /$ day intramuscularly for 45 days, and this was repeated as a second cycle after a 2-week break. The regimen was well tolerated with significant and rapid clinical improvement.

\section{CONCLUSIONS}

We have presented one of the rare presentations of lupoid MCL mimicking granulomatous cutaneous conditions. This clinical form is capable of confusing the most experienced physicians from leprosy and $\mathrm{z}$ ustaleniem rozpoznania klinicznego [5, 14, 15]. $Z$ tego powodu we wszystkich nietypowych przypadkach CL rozpoznanie należy potwierdzić, wykazując obecność pasożyta.

Przyczyny nietypowych manifestacji choroby nie są wyjaśnione, jednak liczne dane kliniczne i eksperymentalne wskazują, że na rozwój i rokowanie w szerokim spektrum postaci klinicznych CL mogą wpływać takie czynniki, jak zmiana odpowiedzi immunologicznej gospodarza, choroby współistniejące, niedożywienie i różnorodność genetyczna szczepów [14-16]. W niektórych niecodziennych postaciach choroby - jak u opisanego w tej pracy pacjenta, u którego nie stwierdzono niedoborów odporności - nie jest jednak możliwe ustalenie związku z głównymi czynnikami ryzyka. Potrzebne są dalsze badania wyjaśniające różnorodność postaci choroby.

Wśród głównych czynników odpowiedzialnych za opóźnienia lub trudności z ustaleniem rozpoznania CL wymieniano zwykle obraz kliniczny imitujący inne choroby $[17,18]$. Istotne znaczenie dla odpowiednio wczesnego rozpoznania i szybkiego podjęcia leczenia tej oszpecającej choroby ma duża czujność diagnostyczna oraz uwzględnianie CL w diagnostyce różnicowej ziarniniakowych chorób skóry. Większość przypadków choroby u pacjentów w Etiopii nie powoduje trudności diagnostycznych i rozpoznanie ustala się na podstawie obrazu klinicznego. U niektórych chorych stwierdza się jednak niecodzienne formy morfologiczne, które wymykają się jednoznacznej diagnozie. $W$ takich przypadkach uzasadnione jest badanie mikroskopowe. Bardziej zaawansowane metody diagnostyczne umożliwiające identyfikację gatunku są zazwyczaj stosowane wyłącznie w badaniach naukowych ze względu na ich duży koszt.

Toczniowa postać CL występuje rzadko. Jest najbardziej rozpowszechniona na obszarach endemicznego występowania leiszmaniozy, zwłaszcza w krajach Bliskiego Wschodu i w Afganistanie. Na podstawie dostępnego piśmiennictwa uznaje się, że najczęstszym czynnikiem wywołującym toczniową postać CL jest L. tropica. Postać ta wykazuje bardzo duże podobieństwo do innych ziarniniakowych schorzeń skóry o podłożu zakaźnym lub zapalnym $[19,20]$. Obecnie w Etiopii często stwierdza się przypadki odmiany toczniowej CL umiejscowionej na twarzy, przypominającej gruźlicę toczniową, trąd lub toczeń rumieniowaty. U opisywanego pacjenta ze względu na koszty nie przeprowadzono identyfikacji gatunku, który wywołał chorobę, ale można $\mathrm{z}$ dużym prawdopodobienstwem przyjąć, że był to gatunek L. aethiopica.

Sposób leczenia zależy od rejonu świata, w którym doszło do zakażenia, gatunku Leishmania, umiejscowienia i stopnia nasilenia zakażenia oraz czynników dotyczących gospodarza, takich jak stan odporności i wiek $[21,22]$. Postać toczniowa CL jest zazwyczaj oporna na 
tuberculosis endemic areas. Therefore, physicians need to be familiar with the different clinical forms of CL to facilitate early detection and proper treatment, resulting in curing the disease, and preventing a psychological impact and further transmission. Moreover, we recommend that MCL should be included in the differential diagnosis of granulomatous dermatological conditions.

\section{CONFLICT OF INTEREST}

The authors declare no conflict of interest. konwencjonalne metody leczenia i może utrzymywać się i rozwijać powoli przez wiele lat [19]. Ze względu na brak randomizowanych, kontrolowanych badań nie ma wystarczających danych dotyczących schematu leczniczego, który powinien być stosowany w terapii postaci toczniowej CL. W czasie ostatnich kilku lat pojawiły się publikacje opisujące liczne metody leczenia tego schorzenia w monoterapii, takie jak krioterapia, maść z paromomycyną, stiboglukonian sodu podawany w iniekcjach doogniskowych, itrakonazol podawany doustnie, flukonazol podawany doustnie, pentamidyna oraz miltefozyna [23-25]. Skuteczność tych metod była zróżnicowana. W innym badaniu wskazano na wysoką efektywność terapii laserem $\mathrm{CO}_{2}$, który okazał się skuteczny u 90\% spośród 24 pacjentów z postacią toczniową CL [26]. W Etiopii leczenie z wyboru opiera się natomiast na pięciowartościowych związkach antymonu $[7,10]$.

U opisanego pacjenta ze względu na niejednoznaczny przebieg toczniowej postaci MCL, prowadzącej powoli do zniekształceń w obrębie twarzy, wdrożono ogólnoustrojowe leczenie antymonianem megluminy podawanym domięśniowo w dawce $30 \mathrm{mg} / \mathrm{kg}$ m.c./ dobę przez 45 dni. Cykl ten został powtórzony po 2-tygodniowej przerwie. Zastosowany schemat leczenia był dobrze tolerowany przez pacjenta i przyniósł szybką, znaczącą poprawę stanu klinicznego.

\section{WNIOSKI}

Przedstawiony przypadek dotyczy postaci toczniowej leiszmaniozy śluzówkowo-skórnej - jednej z rzadkich odmian tego schorzenia, imitujących ziarniniakowe choroby skóry. Ta postać kliniczna może wprowadzić w błąd nawet najbardziej doświadczonych klinicystów na obszarach endemicznego występowania trądu i gruźlicy. Z tego względu lekarze powinni mieć odpowiednią wiedzę na temat różnych postaci klinicznych CL. Umożliwia ona wczesną diagnostykę i podjęcie odpowiedniej terapii, która zapewni wyleczenie i zapobiegnie niekorzystnym skutkom psychologicznym i dalszemu przenoszeniu choroby. Zaleca się ponadto uwzględnianie MCL w diagnostyce różnicowej ziarniniakowych schorzeń dermatologicznych.

\section{KONFLIKT INTERESÓW}

Autorzy nie zgłaszają konfliktu interesów.

\section{References \\ Piśmiennictwo}

1. World Health Organization: WHO control of the leishmaniases. Report of a meeting of the WHO Expert Committee on the Control of Leishmaniases, 22-26 March 2010, Geneva 5-88. Available at: http:/ / apps.who.int/iris/ bitstream/10665/44412/1/ WHO_TRS_949_eng.pdf 
2. World Health Organization: Essential leishmaniasis maps. Available at: http://www.who.int/leishmaniasis/leishmaniasis_maps/en/

3. Alvar J., Velez I.D., Bern C., Herrero M., Desjeux P., Cano J., et al.: Leishmaniasis worldwide and global estimates of its incidence. PLoS One 2012, 7, e35671.

4. de Vries H.J.C., Reedijk S.H., Schallig H.D.F.H.: Cutaneous leishmaniasis: recent developments in diagnosis and management. Am J Clin Dermatol 2015, 16, 99-109.

5. Bari A., Rahman S.B.: Many faces of cutaneous leishmaniasis. Indian J Dermatol Venereol Leprol $2008,74,23-27$.

6. Bari A.U.: Clinical spectrum of cutaneous leishmaniasis: an overview from Pakistan. Dermatol Online J 2012, 18, 4.

7. Padovese V., Terranova M., Toma L., Barnabas G.A., Morrone A.: Cutaneous and mucocutaneous leishmaniasis in Tigray, northern Ethiopia: clinical aspects and therapeutic concerns. Trans R Soc Trop Med Hyg 2009, 103, 707-711.

8. Mengistu G., Laskay T., Gemetchu T., Humber D., Ersamo M., Evans D., et al.: Cutaneous leishmaniasis in south-western Ethiopia: ocholo revisited. Trans R Soc Trop Med Hyg 1992, 86, 149-153.

9. Negera E., Gadisa E., Yamuah L., Engers H., Hussein J., Kuru T., et al.: Outbreak of cutaneous leishmaniasis in Silti woreda, Ethiopia: risk factor assessment and causative agent identification. Trans R Soc Trop Med Hyg 2008, 102, 883-890.

10. Van Griensven J., Gadisa E., Aseffa A., Hailu A., Beshah A.M., Diro E.: Treatment of cutaneous leishmaniasis caused by Leishmania aethiopica: a systematic review. PLoS Negl Trop Dis 2016, 10, e0004495.

11. Seid A., Gadisa E., Tsegaw T., Abera A., Teshome A., Mulugeta A., et al.: Risk map for cutaneous leishmaniasis in Ethiopia based on environmental factors as revealed by geographical information systems and statistics. Geospat Health $2014,8,377-387$.

12. Czepiel J., Biesiada G., Leśniak M.R., Salamon D., Jaworek A., Wojas-Pelc A., et al.: Cutaneous leishmaniasis in a patient returning from Morocco. Przegl Dermatol 2010, 97, 260-263.

13. Harms G., Schlonian G., Feldmeier H.: Leishmaniasis in Germany. Emerg Infect Dis 2003, 9, 872-875.

14. Schwarz K.J.: Diagnosis and differential diagnosis of cutaneous leishmaniasis. Report on seven cases observed in Zurich. Schweiz Med Wochenschr 1970, 100, 2073-2078.

15. Handler M., Patel P.A., Kapila R., Al-Qubati Y., Schwartz R.A.: Cutaneous and mucocutaneous leishmaniasis: clinical perspectives. J Am Acad Dermatol 2015, 73, 897-908.

16. Amato V.S, Tonacio A.C., Alves Mdo M.: An atypical presentation of cutaneous leishmaniasis. Rev Soc Bras Med Trop 2010, $43,481$.

17. Akilov O.E., Khachemoune A., Hasan T.: Clinical manifestations and classification of Old World cutaneous leishmaniasis Int J Dermatol 2007, 46, 132-142.

18. Guimaraes L.H., Queiroz A., Silva J.A., Silva S.C., Magalhaes V., Lago E.L., et al.: Atypical manifestations of cutaneous leishmaniasis in a region endemic for Leishmania braziliensis: clinical, immunological and parasitological aspects. PLoS Negl Trop Dis 2016, 10: e0005100.

19. Khaled A., Goucha S., Trabelsi S., Zermani R., Fazaa B.: Lupoid cutaneous leishmaniasis: a case report. Dermatol Ther (Heidelb) 2011, 1, 36-41.

20. Ferahba A., Mistik S., Utas S., Yaman O., Canoz O., Doganay M., et al.: Cutaneous lupoid leishmaniasis: a case report. Cutis 2006, 77, 25-28.

21. Masmoudi A., Hariz W., Marrekchi S., Amouri M., Turki H.: Old World cutaneous leishmaniasis: diagnosis and treatment. J Dermatol Case Rep 2013, 7, 31-41.

22. Goto H., Lindoso J.A.: Current diagnosis and treatment of cutaneous and mucocutaneous leishmaniasis. Expert Rev Anti Infect Ther 2010, 8, 419-433.

23. Herrmann A., Wohlrab J., Sudeck H., Burchard G.D., Marsch W.C.: Chronic lupoid leishmaniasis. A rare differential diagnosis in Germany for erythematous infiltrative facial plaques. Hautarzt 2007, 58, 256-260.

24. Benmously Mlika R., Hammami H., Sioud A., Mokhtar I., Fenniche S.: Lupoid leishmaniasis of the nose responding well to cryotherapy. Dermatol Ther 2011, 24, 378-379.

25. Nilfrousihzadeh M.A., Jaffray F., Reiszadeh M.R., Ansari N.: The therapeutic effect of combined cryotherapy, paramomycin, and intralesional meglumine antimoniate in treating lupoid leishmaniasis and chronic leishmaniasis. Int J Dermatol 2006, 45 , 989-991.

26. Asilian A., Iraji F., Hedaiti H.R., Siadat A.H., Enshaieh S.: Carbon dioxide laser for the treatment of lupoid cutaneous leishmaniasis (LCL): a case series of 24 patients. Dermatol Online J 2006, 12, 3.

Received: 21.11 .2017

Accepted: 25.03.2018

Otrzymano: $21.11 .2017 \mathrm{r}$.

Zaakceptowano: 25.03 .2018 r.

How to cite this article

Yosef T., Reszke R.P., Szepietowski J.: Lupoid mucocutaneous leishmaniasis. Dermatol Rev/Przegl Dermatol 2018, 105, 534-541. DOI: https://doi.org/10.5114/dr.2018.78074. 